detection capable of identifying ballistic missiles with certainty. Mr. Taylor repeated the assurance given by the Secretary of State for Air on March 3 that no aiternative area was available in Britain and said there was to be very full discussion of the detailed proposals between representatives of the Air Ministry, the National Parks Commission and the Council for the Preservation of Rural England, and while the siting of the radars thomselves could not be modified, he hoped that by careful choice of design and attention to landscaping details, the appearance of the completed station should be such that the disturbance to the natural landscape would be generally acceptable. On the certainty of detection, Mr. Taylor said that the opinion quoted was not sustained by the advice of the distinguished scientists who had advised the Government on the project and that in the view of those scientists the system would work. He was informed that there was no difficulty in distinguishing between ballistic missiles and artificial satellites and that the possibility of confusion between a missile trajectory and an ionization trail was so remote that for practical purposes it could be ignored. The Government was satisfied that this system of radar detection was capable of identifying ballistic missiles with very great precision and, moreover, the station was complementary to other methods of obtaining information about hostile intentions and provided the last stage of tactical warning.

\section{Development of Ballistic Missiles}

ON April 13 the Minister of Defence, Mr. H. Watkinson, in the House of Commons, and the First Lord of the Admiralty, Lord Carington, in the House of Lords, announced that the Government has been considering the future of the project for developing the long-range ballistic missile Blue Streak and has boen in touch with the Australian Government about it. The vulnerability of missiles launched from static sites, and the practicability of launching missiles of considerable range from mobile platforms have now been established, and in the light of military advice, the Government has concluded, and the Australian Government has fully accepted, that Britain should not continue to develop, as a military weapon, a missile that could be launched only from a fixed site. The Government is now considering whother tho Blue Streak programme can be adapted for the development of a launcher for space satellites, and a further statement will be made as soon as possible. There are many other projocts for which the range at Woomera will be needed, and a substantial programme of work for that range for some years to come at least is expected.

In reply to further questions $\mathrm{Mr}$. Watkinson said that the cost of the project to date has been about £65 million and that of completing it would be between $£ 500$ and $£ 600$ million. None of the expenditure would be wasted if it was decided to go ahead with Blue Streak as a launcher for a space satellito. The Americans are investing an immense sum of money in space research, both for its military and its scientific and industrial value, and at present Britain could only get into space by the American offer to launch British satellites. Blue Streak, in conjunction with Black Knight, which has a record of firings practically 100 per cent perfect, is a possible space launching-vehicle, and this combination may give us experience of the utmost military and scientific value.

\section{New Nature Reserve in Scotland}

Strathy Bog, an area of 120 acres in the County of Sutherland, has been declared a nature reserve by the Nature Consorvancy; this brings the total number of national nature reserves in Scotland to 24 with a total area of 101,809 acres. The new reserve is the least-disturbed part of a vast area of bogland which covers the flat or gently undulating moorlands of this district. The ground is extremely wet, with standing water in the pools throughout the year, and Sphagnum moss is prominent in the vegetation, giving a generally spongy surface. In a rich assemblage of bog-plants there are cotton-grasses, sundews, bog asphodel, dwarf birch and bearberry. The area shows certain unusual structural features. Part of the Bog is covered with elongated pools lying parallel to each other, giving the impression that the surface has torn repeatedly under tension caused by the rather fluid mass of underlying peat tending gradually to slide down-hill. Such bogs may thus eventually break up and dry out oven when unaffected by human disturbance.

The Nature Conservancy also announces additions to the nature reserve at Rannoch Moor. The original area was 3,485 acres in the north-east corner of the Moor of Rannoeh. The new area. comprises 200 acres covering a stretch of Loch Laidon and a small area of 19 acres at the southern end of the existing reserve.

\section{International Communications and Scientific Journals}

WiTh the rapid growth of new journals the problem of presenting these journals in a form which will make their contents available to readors in other countries bəcomes more and more acute. To help Englishspeaking peoples, an increasing number of editors in countries oversea are preparing copies of their journals translated into English. Although this practice is highly commendable from the point of view of English-speaking readers, the journals often fail to make the impact they might because of the inadequacies of the translation. It is extremely difficult to translate the highly tochnical language of one country into that of another, and, unless special precautions are taken, a translation may produce effects which are not quite what the original research worker had intended. Recent English versions of journals which emanated from France, Czechoslovakia and Japan all indicate that the translations have been carried out by natives of those countries who 'know English well'. Before publication they would have been well advised to submit their publications to English-speaking men of science who also have $a$ good working knowledge of the foreign language concerned. In this way the circulation value of their journals would be considerably enhanced, and many ludicrous statements would be eliminated. Another solution to what is admittedly a most difficult problem might be greater use of an auxiliary language like Interlingua or Esporanto. A world-wide conference to discuss the matter could be of benefit to men of science everywhero.

\section{Abstracting Scientific Information}

The Review of the International Council of Scientific Unions for July 1959 contains an article by Prof. E. A. Boutry, secretary of the International Council of Scientific Unions Abstracting Board, describing the work of the Board, its story, ideas, 